\title{
Transatlantica
}

Revue d'études américaines. American Studies Journal

2 | 2014

Aesthetics of Theory in the Modern Era and Beyond / Photographie documentaire

\section{Our Tools Make Us (And Our Literature) Post}

Essai édité par Jean-Yves Pellegrin (Université Paris-Sorbonne)

\section{Steve Tomasula}

\section{(2) OpenEdition}

\section{Journals}

Electronic version

URL: https://journals.openedition.org/transatlantica/7102

DOI: 10.4000/transatlantica.7102

ISSN: 1765-2766

Publisher

Association française d'Etudes Américaines (AFEA)

Electronic reference

Steve Tomasula, "Our Tools Make Us (And Our Literature) Post", Transatlantica [Online], 2 | 2014, Online since 22 June 2021, connection on 31 January 2023. URL: http://journals.openedition.org/ transatlantica/7102 ; DOI: https://doi.org/10.4000/transatlantica.7102

This text was automatically generated on 31 January 2023.

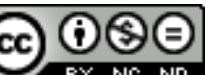

Creative Commons - Attribution-NonCommercial-NoDerivatives 4.0 International - CC BY-NC-ND 4.0 https://creativecommons.org/licenses/by-nc-nd/4.0/ 


\title{
Our Tools Make Us (And Our Literature) Post
}

\author{
Essai édité par Jean-Yves Pellegrin (Université Paris-Sorbonne)
}

\author{
Steve Tomasula
}

\section{The Dawn of Us}

1 At the start of the movie 2001: A Space Odyssey, two tribes of apes get into a fight over a watering hole, and one group drives off the other. The apes who have been driven away are depressed, and just sit around moping when one of them gets the idea to use a thigh bone of some large animal as a club. First he tries it out on a few dried ribs that are lying about, ${ }^{1}$ then he uses it to bring down one of the tapirs that had, up until this moment, lived peacefully among the apes in an idyllic, Garden-of-Eden symbiosis. Suddenly, we are back at the watering hole, more of a mud puddle really, and the ape that invented the club is at the head of his troupe, all of whom are armed with their own bone clubs. The larger, stronger apes are still there, furious at the reappearance of the weaker group. They attack, using all the usual monkey strategies for waging war: shrieks, baring of teeth, pounding of chests and quick feints, during which the individual who'd invented the bone club stands upright-more like a man than an apeand when the leader of the other pack rushes at him on all fours, he uses his club to bash in this ape's brains, and we can't help but be struck by how the tool has made the man. No matter what Benjamin Franklin says about Man being the tool-making animal, it's the tool-the club-that made this ape stand upright: it's impossible to swing a club when walking on all fours; from a hunched-over, ape-like position, you can't get the leverage needed to swing a tool to chop wood, hit a golf ball, win wars....

\section{Jump Cut 1450}

2 In the film the ape-man celebrates his victory by throwing his bone-club into the air, and we follow it in slow-mo as it rises, rises, keeps rising, then is suddenly replaced by a 
space shuttle in the year 2001, the title of the film-and used here (in this movie made in 1968, a year before the moon landing) as an icon for the height of civilization, the space station pirouetting to Strauss's Waltz of the Blue Danube, the pinnacle of that technological journey began by that distant ancestor who discovered a way to leverage power through his low-tech tool. But I'd like us to imagine that bone turning into a book, for a book too, is a tool, and perhaps contributed more to making us human-in the humanist sense of the word-than any stone axe, plow, compass, or gun....

That is, in his fiction, Kubrick has given us an image for a history.

4 So imagine that bone club rising into the air, then turning into Gutenberg's printing press: the tool that allowed us to disseminate humanist thought and help create Renaissance individuals with unique, individual features like those depicted on the Sistine Ceiling instead of the generic types seen in much Medieval art; think how those depictions of faces might have helped a person think of him or herself as an individual -the "sole proprietor of his own person and capacities... in that he owes nothing to society for them"-in the words of C.B. Macpherson (Lukes, 113). In contrast to the generic, character types in medieval mystery plays written by anonymous authors, unique, individuals began to emerge in literature: Rousseau's Confessions, one of the first works to consider the self as a subject worthy of literature; Ronsard's poetry, in which Jean Marie Goulemot sees the emergence of the lyric "I"; the essays of Montaigne, in which the individual is put forward as the standard by which to measure the world, and which Shakespeare drew upon to invent the soliloquy, that window onto an individual's private struggle and self analysis (391).

5 Let the bone rise a little higher before turning into the cheap, paperback book made possible by steam-powered printing presses, pulp mills, automated type-setting, railroads, and the newsstands selling stationery and books installed by W.H. Smith \& Son at stations along the way: the first "chain" bookstores-the modern world....

6 "It is impossible to exaggerate the importance of the novel in publicizing $18^{\text {th }}$ century private life," Goulemot writes (384). Thus Montaigne is a watershed between the assumptions of knowledge and the relation of the individual to society held by those before, and those who would follow. Before writers like Montaigne and Rousseau, it was a vanity, if not sinful, to dwell upon the individual self to the degree one would need to write, for example, an autobiography, for the self as we would think of it did not even exist. Retiring into a study or library to cultivate this inner self, as we might think of it, would have been seen by most as a kind of "moral pathology" (380). Ian Watt writes that the symbiotic relationship between the novel and the humanist individual it helped bring into existence couldn't come into being until societal conditions made possible the autonomous individual who prospers or fails by jockeying among others in a web of social situations. What's more, the autonomous individual, especially within the middle-class, had to be taken seriously enough to be a subject for literature-for both writers and readers.

7 To cite one of Watt's examples, the institution of marriage in which the woman makes a free choice of a mate came about soonest in England and was probably a contributing factor to the rise of the novel, that $19^{\text {th }}$-century laboratory of romantic scenarios (132-77). That is, a culture's collective thought can produce concrete consequences, such as institutions like marriage, and one of these consequences in $18^{\text {th }}$-century England was the first-person novel itself: an artistic solution to the redefinition of humans and their relationships that resulted from a belief in empiricism and the 
autonomy of the individual: the "emergence of a new ideology of merit" in Goulemot's words (384). To gauge the rise of the individual throughout the $18^{\text {th }}$ and $19^{\text {th }}$ century, consider the number of novels of this era that bear the name of the main character as title: Clarissa, Pamela, Robinson Crusoe, David Copperfield....

8 That is, new modes of thought and the new social orientations they are influenced by and help bring about also bring into existence literary techniques, as is perhaps the most clear in Modernism: WWI, WWII, the absorption of Freud, Marx, Einstein and others brought about changes in thinking that made faith in rationalism and its accompanying social order impossible. Consequently techniques such as a fixed point of view became obsolete. In their place rose literary innovations such as those created by Henry James by which inner consciousness is portrayed; in contrast to the $18^{\text {th }}$ century novel, the subject of many modern novels is seldom what happened. Rather it is more often how and what someone thought they thought (compare Impressionist painting). In other words, in a world that is seen as relative, the Modernist use of viewpoint can become an instrument to explore not only a newly emerging culture but also the perspectives from which it is seen (consider Cubism in the visual arts). The same can be said of stream of consciousness, fragmentation of the narrative, the use of irony as a master trope and other narrative devices common to Modernist novels. In fact, the hero's alienation and/or salvation through art, or purity of idea, can be seen as a defining characteristic of the Modernist novel. So can the individuality stamped into each work-one can pick out a Hemingway novel, for example, upon hearing a single sentence. $^{2}$

\section{Jump Cut to Today}

9 If that ape had thrown his bone high enough for it to morph into an icon of 2014, maybe instead of changing into Gutenberg's press, or a spaceship, it would have changed into an iPad: a tool with about 32 million times the computing power (128 GB) of the computer aboard the NASA Eagle that first landed on the moon (2k of programmable memory and $32 \mathrm{k}$ of storage). Unlike that anonymous individual ape who first used a femur to bash-in the head of a competitor, and launch us down the evolutionary path we continue to follow, the invention of the iPad stands on the shoulders of too many people to even imagine, and who have also made possible a network of tools that have literally shaped life around the globe. I can pull from my pocket a "bone club," that is my phone, and use it to set in motion a factory in China that will customize an iPad, and have it delivered to my door thanks to transportation, communication, and financial networks that work as one. We're all global now. Our tools have pried destiny from biology, and allowed people to alter the shapes of their noses, teeth, thighs, breasts, butts into dimensions fashionable at our time; indeed our tools allow our very DNA to be edited, patented, and rearranged like any other data. Instead of wielding bone clubs, we increasingly fight our wars by unleashing cyber weapons to bring down an opponent's information infrastructure, or factories, or power grid; we do the actual killing remotely with flying robots; we coordinate our revolutions through social media; and of course, governments, corporations, and other organizations exert what control they can over us through spyware that goes far beyond the optical metaphors of surveillance in play when Orwell was writing 1984. 
Though much has been made about the NSA's gathering of the data our phones send back to phone companies as part of their normal operation (simple digital pings that allow us to stay in constant contact by locating the network's nearest antenna) for some time we've understood that with each update to the apps on our phone, it has moved a little closer to becoming a tracking device that we carry around for various corporations in exchange for the convenience of being able to use these same devices to check the weather, look up directions, find a coffee-shop, translate a language.... Every time we make a phone call, use a charge card, or use bits to write a love letter or file for divorce, i.e., do most of the things living in the developed world entails, we leave a digital trace. Or rather, lots of traces. An average, middle-class American generates 1.8 million megabytes of data each year through his or her phone calls, movie downloads, emails, word files, web searches, posts, likes-dislikes, purchases, etc., and all the meta-data about themselves that these activities generate to move through the Internet. By 2015, this will amount to 5.6 zetabytes ( 5.6 followed by 21 zeros) of information per year: an ever-denser data ecology integrated with our lived lives (Tucker). This same average American has no idea how much of this ecology is being harvested for analysis, ${ }^{3}$ but in Europe, where the privacy laws are stricter, it's easier to get an idea: some people who have sued to find out what Facebook keeps on file about them have been handed dossiers that range from over 800 printed pages (the length of War \& Peace) to files so large they were impractical to print out (an achievement far beyond Stasi) (Tucker). If you are married but visit dating sites, Facebook knows this; if you are unmarried and visit dating sites, Facebook knows this also, and will use these and other "facts" to compose a portrait of who the company thinks you are (a portrait, created through the narrow lens of algorithms, that at best can only have a cartoon resemblance). And this is just one entity that has taken an interest in our behavior. Unlike Orwell's world of 1984, we have lots of little brothers monitoring our behavior. Wal-Mart is a single business comprised of 4,700 interlinked stores that continually feed a database of over 100 terabytes of data-the equivalent of more than five times the entire contents of the U.S. Library of Congress (Mau, 129). Acxiom, one of many data brokers that compile databases, offers 500 pieces of information on each of more than 500 million individuals, which it is able to massage for patterns that other companies, government entities, or anyone willing to pay, might find useful (Tucker). Rapleaf, another data broker, has at least one data point associated with more than $80 \%$ of all U.S. e-mail addresses; Corelogic has property-specific data for over $99 \%$ of U.S. residential properties; Datalogix, which has a partnership with Facebook, holds marketing data for almost every U.S. household (Ramirez 25, 26, 29, 38).

11 The affairs and mistresses of public figures like ex-CIA director General David Petraeus, or President Holland have been discovered by analysis of patterns in metadata extracted from the "data ecology" they, and we, generate as we move through our daily activities; likewise, sources used by journalists to investigate stories like these have themselves been revealed through the same techniques. Fatal drone strikes have been called down on targets identified by patterns of pings. In fact, simply knowing where someone travels, one judge noted, would allow others to "deduce whether he is a weekly church goer, a heavy drinker, a regular at the gym, an unfaithful husband, an outpatient receiving medical treatment, an associate of particular individuals or political groups and not just one such fact about a person, but all such facts" (Ball). ${ }^{4}$ 
But of course a person's travel pattern is only one "such fact" itself. Combining location data with other databases - the log of the phone numbers we dial, or text to, the URLs we visit, e-mail addresses we receive and send to, the merchandise we buy, hotel rooms we rent, medicine we take, music we listen to, and books we buy or check out from the library-allows the picture to be colored in with higher and higher resolution. Combining it with the information gathered on others in our social network multiplies the effect: the locations we visit tied to postal codes which are linked to race demographics, which are linked to income and tax records, which are linked to graduation records, and crime records, which are linked to driving and car ownership records, which are linked to those of your children who are themselves tied to their text messages which indicate they leave school each day at 3:45 to meet your spouse whose iPhone reports back to Apple that she sets her alarm at 1 a.m. each morning, but wakes up only five hours later at 6:30 a.m., and whose car leaves the parking garage at her job at 3:30 p.m.-too late to pick up your children without speeding-except on Monday, Wednesday and Friday, the days it is your turn to pick them up, and she instead signs in at a health club that sells this record of her workout habits to a data broker who combines it with patterns from your family, before selling the sum to a vitamin manufacturer who sells it to the insurance company you've applied to, which also buys databases of investment portfolios, credit ratings, and hundreds if not thousands of other points that it might find useful to determine who you are, and assess what kind of risks and opportunities you might present.

Along with the more mundane uses of targeting ads, monitoring employees, arresting suspects, tracking disease spread, algorithms have been created to generate information maps for purposes ranging from reconstructing a person's social security number (combining public records for places of birth, and birthdates gleaned from online greetings) to identifying which Facebook pages have been posted by homosexuals (with 78\% accuracy) (Lohr 2010). Indeed, though sites like Facebook and Google have long ago automated the collection and analysis of personal information, the sophistication of computing power and ever-plunging cost of memory is now making it possible to do so on the fly and in real time, so for example, if the 111 megabytes of photos and videos Facebook stores on each of its billion users are fed to a device like Google Goggles, you'll be able to walk down the street and identify people you pass. And by identify, app developers don't mean you'll simply know their name and address, but income, sexual orientation, politics, taste in music, or propensity to like or dislike a person with a profile like yours. And of course, Google is gathering data on what attracts your attention for its own purposes, mining the movement of your cursor, i.e., the movement of your eyes, for example, and using algorithms to construct an image of what you might be thinking.

We know all of this (E-mail is often said to be a euphemism for Everyone's-Mail, i.e., mail everyone can read). Yet we do not give up our Internet connections, ATM cards. Just the opposite. We ourselves engage in deeper levels of this behavior, relying on googling a potential romantic or business partner, or checking the credit rating of a possible renter; we assume we are tracked, even as we track the movement of employees, pets, or our children, or monitor their television or computer use at home, or the number of keystrokes a subordinate types at work... The deeper this behavior penetrates our lives, the more we find the boundaries between the self and the crowd not just an inconvenience but anti-social, for, as in voting, it is only in the aggregate 
that we matter. And everyone knows it is uncivic to not vote. That is, unlike the ubercivic citizens of Orwell's dystopia-and this is also a difference between us and the high Moderns-the vast majority of the personal information that is available for use by others has been made available by us, voluntarily, or at least indifferently, in exchange for the ability to use a charge card, play Angry Birds, order a pizza, call a cab, pay a water bill, renew a license, buy a song, send a greeting or invitation. Facebook alone accounts for 25 billion voluntarily "shared" exchanges each month (all of which are "shared" with Facebook itself, of course), while others, embracing the concept of the self as revealed by data create visualizations of the metrics generated by their own dayto-day routines: pointillist self-portraits, so to speak, in the form of graphs or other visualizations depicting their weight over time, for example, or sleep patterns, mood swings, movement, location, alertness, productivity, sex, noise levels, dog walks, pastry consumption, restaurant check-ins, heart rate, posture, and dozens of other metrics, often aided by several of the devices people can wear to monitor and broadcast these measurements. ${ }^{5}$

We do so to tell stories and paint pictures of who we are, down to the "last redoubts of the personal," as Gary Wolf puts it (2010). Like the novelists of old, we might add. ${ }^{6}$

The degree to which the above description is familiar, even quotidian, is one indicator of the degree to which the individual as C.B. Macpherson (or even Camus) meant it, an autonomous individual made possible by the concepts of separation and privacy, is being undermined by new social formations. We may not have reached the point expressed by Facebook founder Mark Zuckerberg: that privacy is "no longer a social norm," i.e., no longer expected, or even wanted (Johnson). But the view of computer scientist Arvind Narayanan seems accurate: according to him, the amount of data that each of us generates just by living, the incentives to mine this data, and the increasing power and decreasing cost of the tools used to do so have already brought us to the point where "anonymity of any kind may be "algorithmically impossible"' (Tucker).

Therefore, a question: If the bone-club compelled our early ancestors to stand upright, if the printing press contributed to the rise of a humanist individual from a communal, medieval consciousness, what sort of human do our tools encourage today?

\section{Into the Jungle}

18 The mutually reinforcing and generative networks of technology (especially media technology), and conceptions of the self-and their expressions in art and literatureare revealing for separately they are lower orders of collective, emergent behavior, or Weltanschauung as it might have once been called. And it is widely acknowledged that the move to digitalization has been the most profound development since the printing press (as Katheryn Hayles reminds us, even paper books are now digital if their composition, manufacture, and distribution are taken into consideration). It is beyond the scope of an essay to tease out how these aspects are all of one cultural fabric but the example of Amazon.com is instructive for it is one node where our tools, books, reading habits, authorship and other expressions of self come together in the mining of data. Indeed, Amazon.com (named after the volume of earth's largest river) is so closely associated with books that it's surprising to learn that the company was never primarily about books. Rather, as George Packer writes, the raison d'être of books at Amazon has always been data. Founder Jeff Bezo's "stroke of business genius," as 
Packer puts it, was to recognize the power of the Internet to gather data about people and how selling books, back in the early days of the Internet, could be the simplest and most direct way to use this new technology to get the names, address, and other demographic information on a broad swath of shoppers (everyone buys books, from repair manuals to philosophy), but especially those shoppers with the most disposable income (the educated). By using the bait of books at near-cost, and even below cost, Amazon could capture the data on huge numbers of shoppers, then use it to target the sales of everything else-from fine art to plumbing supplies (Packer). ${ }^{\text {? }}$

And indeed, now that Amazon has matured, books only make up about $7 \%$ of its $\$ 74.5$ billion dollar annual sales (Market Watch), though more pertinent to this discussion is the fact that the books Amazon does sell make up about $60 \%$ of all books sold in the U.S.: i.e., Amazon sells more books than all other bookstores in the U.S. combined; in addition, in 2013 it sold $90 \%$ of all digital books; its total sales also dwarf the combined earnings of all of the conglomerate publishers in the U.S. (Packer). By every measure, then, Amazon is the giant whose slightest shiver is an earthquake in the rest of the reader-writer culture/economy. Thus the endless discussion among publishers, readers, authors, booksellers, and others who feel the literary earth move every time Amazon takes a step.

Paradoxically, this dominance was achieved by fragmenting (some say destroying) ${ }^{8}$ all other aspects of book culture, "eliminating gatekeepers" as Bezos refers to anyone (other than Amazon) who gets between the author and reader, i.e. book reviewers, publishers, acquisition editors, or bookshop owners who might curate their shelves.... The bone-club Amazon uses to bash in the skulls of those knuckle-draggers from another era is, of course, the algorithm, the data mining, the surveillance and modeling techniques described above. Once styling itself as a 'virtual bookstore' or 'book-culture hub,' Amazon's early days contained author interviews and staff members who wrote reviews, and did other kinds of activities to mimic a hybrid bookstore / reviewmagazine. But by 2002 its transformation from a virtual bookstore to an automated database was complete. Gone were the reviewers, for example, replaced by a database of book rankings by customers who also provided the added benefit of supplying even more demographic information about themselves by writing reviews (for free) about the books (or shoes or rice cookers or lawn mowers) they bought, and when combined with databases of customer history, and analytics that employed statistical probability, Amazon could predict with uncanny accuracy what else a customer would want to buy. ${ }^{9}$ Indeed, Amazon recently patented what it calls "anticipatory shipping," a program that uses a customer's past buying habits to stock items that they "do not yet know they want" (Kopalle) in whichever order fulfillment center is nearest to the customer's address (e.g. a shopper who buys a book about baby names doesn't yet know that she'll also want a rectal thermometer). It may be, as Fredric Jameson once asserted, that it is easier to imagine the end of the world than the end of capitalism, but those born after the birth of Amazon may find it odd that people once said the same thing about bookstores.

21 And publishers. On the pre-press side, Amazon has also wielded its weight to flatten literary "gatekeepers," especially agents, and publishers, putting the power of publishing, as it had done with book reviewing, in the hands of the masses. Under 14 different imprints, Amazon itself now brings out about 700 books a year, serving as publishing "partners" with authors. Its self-publishing platform allows anyone to 
publish their own book in print, or as a Kindle e-book, or as an audio book. The incentive for authors to bypass the traditional network of Agent-Publisher-PrinterDistributor-Seller and go direct to the reader is obvious. Publishing with Amazon, an author can keep up to $80 \%$ of a book's price as opposed to the typical $15 \%$ of a hardback sale. Further, the stories of unknown writers being rejected by agents and publishers before going on to success by self-publishing on Amazon have stopped being news because there are so many ${ }^{10}$ (Jasiewicz, 47).

But even if a self-published author only sells copies to his or her mother, Amazon wins. Here we are reminded that during the 1876 Gold Rush in America, few prospectors found much gold, but the big winners were the men who had the foresight to sell shovels. And sell shovels Amazon does, providing the tools for an unlimited number of authors to prospect for the next big hit, all the while driving down prices (remember Amazon's original business model).

Factories with no human employees, automated offices, or stores like Amazon; classrooms replaced by MOOCs in which a single professor might instruct a million students: our tools-digitalization-are transforming nearly every sphere of our global economy, and driving the marginal cost-the price of producing one additional unit after the initial start-up costs are paid-ever closer to zero. Why wouldn't this revolution transform our cultural products? And therefore their creators: authors, artists, and musicians? As well as their users, e.g. readers? The cost of raw, digital culture has been near zero for some time, as Napster revealed, reducing music to digital content and destroying the traditional music industry, a phenomenon that has since spread to print journalism, for example, and is now transforming publishing of all kinds. Or as Bezo's puts it: "Amazon is not happening to bookselling, the future is happening to bookselling" (Packer).

This is not without consequences for "what counts as literature," and from this perspective the picture is more Cubist: from one point of view it is easy to see that though Amazon has done much to narrow publication, distribution, and selling to a single channel, itself, it has done much to also expand choice; it has given access to books unimaginable by someone, for example, whose only bookstore may have been the bland, book (and greeting-card) seller in a shopping mall. For authors, it has given access to readers unimaginable at any time previous: even the most esoteric poet now has access to a distributions web that covers the globe. Yet by treating all writing as digital content, by relying on algorithms to push those books with the greatest proven capacity to sell in large numbers, a conception of literature as high-turnover, mass entertainment, is also being promoted.

As J. A. Konrath notes, he makes as much selling a $\$ 2.99$ ebook as he would from a $\$ 25$ hardback. The cost of a cup of coffee (Jasiewicz, 47). In the process, do people come to think of literature as a cup of coffee?--something cheap, easily consumed, completely forgettable?

We've seen this phenomenon before. Indeed, every revolution in publishing has been accompanied by a further democratization of text, which some see as a lowering of standards. The invention of the printing press meant the debasement of what had been sacred objects; the proliferation of texts that followed resulted in the secularization of books-a turning away from God-accompanied by a rise in literacy, which meant that peasants could read, and interpret "incorrectly," what had once been the province of experts. Closer to home, when the 40+, major, New York, independent publishing 
houses like Little Brown were being consumed by ever-merging conglomerates (as of this writing all are owned by one of 5 conglomerates), when mega bookstores like Borders were systematically killing off independent bookstores (locating themselves near successful ones, for example, and then underselling them to suffocation), it was common knowledge that the emphasis would be on sales not literary "quality." With its emphasis on size and growth, every time an independent publisher was acquired by an ever-larger conglomerate (which were themselves a chip in an "entertainment" portfolio of casinos, theme parks, cable-TV channels, etc.) literary acquisition editors were replaced by business managers willing to pay huge sums for the rights to romance, horror or other genre titles in the hopes that one of them might become a blockbuster hit; they paid for these rights by turning their backs on, for example, poetry, or the literary, or "difficult" novel that had no chance of ever selling in those kinds of numbers.

Novels that sold 20,000 copies thus became "failures" in the eyes of publishers, and invisible to readers, whose attention was ever more re-directed by advertising dollars to Best-Seller lists, front-table displays, or TV promotion. When Amazon came on the scene, it viewed these conglomerates as "antediluvian losers with... warehouses full of crap."

\section{Beauty is in the Eye of the Beholder, Even if the Beholder is an Algorithm}

When launching its publishing effort, one of Amazon's first books was "My Mother Was Nuts," a memoir by an actress from an old TV-sitcom, (Penny Marshall of "Laverne \& Shirley" fame) that Amazon paid $\$ 800,000$ to acquire (Packer), which makes one wonder, given all their data and algorithms, given the power to predict "what customers don't yet know what they want," is this what their models told them to publish? Maybe the explanation lies in an algorithm's inability, or rather, Amazon's refusal, to make any distinction between "content people" (i.e. what were once known as authors, editors, critics, translators, sophisticated readers and other literary types) and "business people"."11

29 Literary judgments aside, it is the big-data approach to literature that is of interest here, the change in literary landscape that makes it possible for a 17 year-old highschool student to bypass the entire literary establishment by posting her novel, The Kissing Booth, on a social reading site like Wattpad, and have it read by 19 million readers (and then land a 3 book contract with one of the conglomerate publishers, Random House/Delacorte ). Among the 20 million other writers communicating directly with readers through Wattpad is Denny (a.k.a. Have You Seen This Girl, a.k.a. Ate Dennysaur), whose novel Diary ng Panget (Diary of an Ugly Girl) attracted more than 16 million readers/reviewer/commenters, as well as a publisher in the Philippines, where it also became the best-selling print novel of 2013 (Wattpad). Which is to say, barriers of all kinds are being blurred by numerous entities, not just Amazon, and the reading/ writing tools that did not exist until recently: apps for reading on phones; reader-created, custom magazines; Blurb, LuLu, Wordclay, and other platforms that allow readers to connect directly with each other, and writers to connect directly with readers, and all the rest of the new publishing landscape built on an infrastructure of 
data, pattern, algorithmic analysis: Twitter, Facebook, Tumblr, YouTube, Instagram, Vine....

30 A conception of the self as pattern may or may not have fully changed our conception of the human, but it is certainly changing our conception of the reader. Best-seller lists have always been (curiously) part of book review sections (instead of the financial page), but never have the audiences they reflect carried such weight; critics both in and outside the academy vote on literary merit through their selection of which works warrant critical attention, and it is no longer odd to learn of novels like Stephanie Meyer's teen-vampire romance Twilight novels being taught in literature courses, or a self-published novel like E.L. James's Fifty Shades of Grey reviewed in serious newspapers, or discussed by academic panels.

31 Concomitant with this turn toward literature as mass phenomenon is "Distant Reading," the term Franco Moretti gives to the practice of using big-data methods to read across thousands of books, mining the contents for patterns that reveal intangible structures. Thus (to cite a simple example), using tools such as Google's Ngram Viewer (https://books.google.com/ngrams), which can graph the usage of phrases found across $5+$ million books, a reader of American literature might find it useful to discover that authors began writing "The United States is" more often than "The United States are," that is, thinking of the country in the singular rather than plural, around 1874 (about 10 years after the American Civil War) (Wilkens). (Or that the use of the word "posthuman" began to increase exponentially in 1990.) It is the pattern extracted from a mass of textual use-not the singular word use-that can show a historic progression, Moretti claims. In Graphs, Maps, Trees: Abstract Models for Literary History, he shows how distant reading of the topography described in "village novels" maps a social space, and "why village stories organize themselves in circular patterns: a circle is a simple, 'natural' form, which maximizes the proximity of each point to the centre of the 'little world,' while simultaneously sealing it off from the vast universe that lies outside its perimeter." (44) Tellingly, his use of computational or distant reading of thousands of novels reveals patterns in word use that show a very different sense of social space than that which latter emerged in Victorian novels, for example, where it was replaced by a "web of commercial reciprocities." (49). (And, one we might add, seems destined to give way to a sense of social space that is virtual.)

Given, as Moretti says, that "geometric pattern is too orderly a shape to be the product of chance" it "is a sign that something is at work here-that something has made the pattern the way it is" (56). Stepping back for a broader view, we can see that the same can be said for the practice of Distant Reading itself: the increasing computing power; the availability of data bases; a changing cultural climate, e.g. our tools, as well as an ethos that thinks of reading for pattern a worthwhile way to read. "For every genre" Moretti writes, "comes a moment when its inner form can no longer represent the most significant aspects of contemporary reality..." (62).

"Paradigm shift" is the term Thomas Khun used to describe how widely shared assumptions in the sciences will suddenly be abandoned for a new model. While the concept of paradigm shift maps less tightly onto literature and the arts than the sciences (because its easier in the arts for competing models to exist simultaneously) it helps explain why literature or art has a history at all: The world changes, and so must conceptions of literature if they are to say something meaningful to their moment. Medieval art gives way to the art of the Renaissance; High Modernism gives way to 
postmodernism, which gives way to? What? Though a survey of contemporary literature would show a huge variety of aesthetics, and authorial stances, are our tools contributing to a body of writing that can be called Postliterature Literature? Does this literature contribute to (and in turn reinforce) a posthuman conception of self as pattern?

A few points of reference: instead of the stereotype of the lone author or artist slaving away in the solitude of a garret, we have social-media driven self-publishing on sites like Amazon and publishing platforms like Wattpad.com, both described above. On Wattpad alone, 18 million users shared 300 million messages about each others' writing in 2013 (Wattpad). "Find your voice" was common advice to would-be authors searching for what was unique, or original in their own writing at a time (High Modernism) when people believed in concepts like "originality," "genius," "uniqueness"-a Faulkneresque signature style, for example. ${ }^{12}$ For the generation of writers coming up through social writing sites like Wattpad, there is pressure to not think in terms of individual voice but in terms of genre (fan-fiction, horror, werewolf, romance, etc.); there is pressure is to blend in, or to embody the community the way writers for television try to speak to the majority: scripts that may be smart but not so smart that they alienate less-educated viewers; fresh, but not so new as to challenge conventional morality (e.g. there were no people of color in fictional TV shows until it became socially acceptable for corporations to publicly court minority groups as potential markets). Indeed, it's becoming increasingly difficult to not only tell which text was written by which author(s), but if a text was written by any human at all.

\section{Post-Literature Literature}

I'm referring here, of course, to the body of writing in which the erasure of the individual is, in fact, a value to be aspired to: appropriation as creation; repurposing of texts; poetry written by machines-writing in which the computer is integral to its composition and reading, but even more to work that is informed by an accompanying posthuman ethos-one that is at odds with an ethos based upon the uniqueness of the individual, and its cousins, especially originality.

This ethos is at work in literature that is partially generated by the computer though published in print, e.g. Flarf, or Google-sculpting, in which words harvested from the web are collaged into poetry. Nick Thurston's of The Subcontract, Or, On The Poetic Right is a volume of 100 poems that he "wrote" by subcontracting the actual writing through Amazon.com's Mechanical Turk, a crowdsourcing platform that allows employers to hire laborers (called Turks) to perform tiny tasks (such as categorizing photos) that computers are unable to do well. Thurston selected poems produced by workers performing these Human Information Tasks (HITS as they are called) at the rate of $\$ 0.05$ per line, and composed his book by arranging them in the order of efficiency (cost vs. poetry produced), along with the metadata documenting their employeeemployer exchange. For example, one poem produced by employee A7J4Y6FOPZ8YV in 16.5 minutes, at a labor cost of $\$ 3$, begins:

Feel my love; just feel my love as anger or feel my love as hatred or feel my love as burden or feel my love as a sin or feel my love as a crime but just feel it baby feel my love in silence or feel my love as disturbance or feel my love as vacuum but at-least feel my love; feel my love.... 
Another work of literature employing Amazon's Mechanical Turk is Emoji Dick, a translation of Herman Melville's Moby Dick into Japanese emoticons. The novel's famous

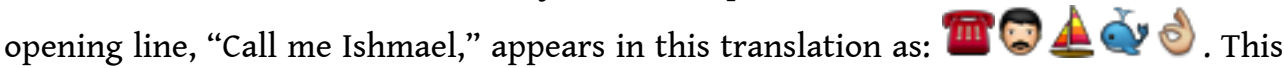
and all the other 10,000 sentences of the novel were translated by 3 different Turks at the rate of $\$ 0.05$ per line; these 3 translations were then voted on by other Turks (at the rate of $\$ 0.02$ per vote) and the translations that received the most votes were included in the book. More than 800 "authors" spent approximately 3,795,980 seconds "writing" this book (whose publication was made possible by a crowd-funding Kickstarter campaign). Jason Huff wrote Autosummarize by using Microsoft Word's summarizing feature to condense 100 of the most popular copyright-free books to 10 lines each. Phil Chernofsky's 1,250 page book And Every Single One Was Someone reproduces a single word, Jew, 6 million times to invoke the Holocaust....

Similar gestures are made through the vast amount of poetry written by machines: "Build an engine with words. Let it make you speak," reads the epigram to Bill Kennedy and Darren Wershler-Henry's apostrophe, the hardcover edition of a poem that they automated by placing on the web, then renaming the Apostrophe Engine. Click on any line in the poem and that line will be plugged into a search engine which returns pages beginning with "You are" and ending in a period. It then compiles the results as a new poem, such as one that begins: "you are old, Father William, the young man said •you are prepared to follow the rules..." (Kennedy and Wershler-Henry, 192).

In Perl poetry, human language is translated into a programming language, Perl, but in a way that allows the Perl poem to still be compiled (i.e., run on a computer), and sometimes also output human language. In this poetics, the commands themselves comprise a vocabulary that has meaning in two worlds: that of humans, and that of the machine. Its best-known example, "Black Perl," reads as a mundane string of words that are also computer commands:

BEFOREHAND: close door, each window \& exit; wait until time. open spellbook, study, read (scan, select, tell us); write it, print the hex while each watches, reverse its length, write again;.... (Jonadab, 2003)

While the language of this poem may be flat, as a program it still runs, though it won't calculate taxes or perform any pragmatic function (a characteristic that is true for most computer-language-human hybrid poems). Obviously, this poem doesn't give readers what they might expect from, for example, lyric poetry. Indeed, the impulse to put "poem" in quotes when discussing code-work "poems" comes from its constraints on human language, which result in a narrowness of vocabulary, rhetorical strategies, flexibility of language and the other pleasures that make poetry, in the traditional sense, poetry. But that, of course, is besides the point; rather it is a form of literature that has more affinity with conceptual visual art, or, in the broader context of the written works described here, a kind of PostLiterary Literature.

\section{Consider, for example, Nick Montfort's "ppg256-1":}

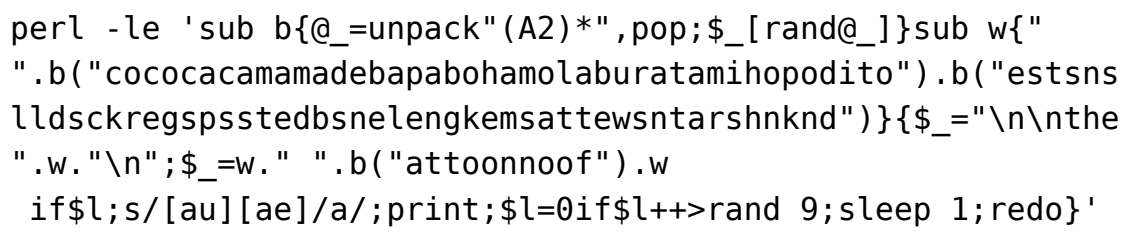


run, this code-poem generates random words without referring to any lookup table, thus creating a string of words that can be found in an English dictionary, as well as words that are strings of random letters, or call it sound poetry/noise; it also applies line breaks in order to supply titles and what Montfort calls an "overall stanza/strophe shape" to its output, that is, to sculpt the output into the appearance of poetry:

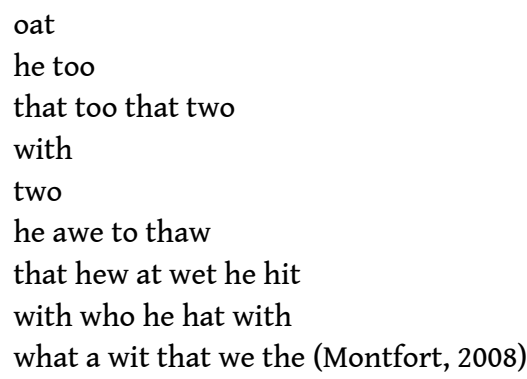

ontfort describes other iterations, and his own experiments with changing the coding, adding a rhyme scheme, for example, by having the program load into memory the last syllable of an output line, and incorporating a command to use this saved syllable at the end of the next output line (the result of which, Montfort reports, caused the computer to make up words to rhyme-something people often do, scrolling though a mental list of words, real and invented, when trying to find a match).

In a sense, this Perl poem automates the experiment of Raymond Queneau's $100,000,000,000,000$ Poems, a traditional fourteen-line sonnet that Queneau layered on top of ten other fourteen-line sonnets in such a way that any one line can be combined with the thirteen lines of any of the other sonnets, thus allowing a potential reading of $10^{14}$ sonnets (Queneau, 14-33). That is, it generates more poetry than can be read in a lifetime. And as it is the form of Queneau's book that allows the poem to proliferate, so it is the form of Montfort's "book"-the software-that generates the poetry (thus, the poem's title).

Queneau's poem, "ppg256-1" asks, What is the nature of poetry? What is the role of the author? Of the reader? of "authenticity"? -questions to which Montfort's poem adds, How does the introduction of the machine into the writing of the poem alter our answers? Especially when a single computer can write more poetry than can be read in multiple human lifetimes? Later editions of "ppg256-1" allowed the reader to pause the output, making it possible to appreciate its Dada-esque qualities, but more importantly its apparent "sense-making" ability-or is it ours? - which prompts the questions, What are we to make of the human impulse to assign meaning? Or agency? How is our conception of 'reading' or 'writing' changed by the complementary gesture of creating a machine that will read this poetry? -at speeds beyond the human capacity to keep up with its generation?

Philip M. Parker alone has written over 200,000 books, ranging from poetry to food security. Or rather, his machines have. As he explains, the process his software used to write over 1.3 million poems (as well as his other books) is an algorithm that employs graph theory and a metric for linguistic differences across word strings in other poems. Yet Parker's poetics is antique when compared to Artificial Intelligence systems designed to process natural language, such as Watson, the IBM system that defeated two former champions of Jeopardy, the quiz show in which contestants compete by answering questions from a variety of general-knowledge categories. 

writing of other machines but make judgments that affect us-that is at stake in Christan Bök's Xenotext Experiment: a plan to compose poetry (one code) that can be translated into the genetic alphabet of DNA (another code); like Perl Poetry, it can "run"; that is, it will be "expressed." In Bök's code poem, though, it will be expressed not as speech, nor on screen, but as a living organism, specifically, the DNA of the Deinococcus radiodurans bacteria, altered so that it carries Bök's poetry within its genes. By replicating and mutating, the bacterium creates other code poems. It is both book and writing machine. As writing machine, the descendants of Bök's original poem could be generating texts long after humans have ceased to exist. But if a poem is written and there's no human left to read it, is it still a poem? If a computer plays chess (or Jeopardy) against a human are they playing the same game? These questions go beyond the academic, especially in light of the ways that science and the writing technologies they give birth to (e.g. the printing press, the telegraph, the radio) have always reconfigured the world.

The diminution of the individual against the backdrop of the machine and the Noachian flood of text enabled by the machine seems to be at least partially the impetus behind the number of authors who have abandoned writing, and merely represent "found" text as their own. Within this growing corpus of work we can count:

David Buuck's "United 93" (a representation of the transcript from the black-box flight recorder aboard the flight that crashed into a Pennsylvania field on 9/11).

Counterpath Press's publication, as poetry, of Let Her Speak: Transcript of Texas State Senator Wendy Davis's June 25, 2013, Filibuster of the Texas State Senate (which is just what its long title says-a transcript of the words Senator Davis said during the 11 hours she occupied the podium in the Texas State House in order to use up the time allotted for voting before a bill restricting women's access to health clinics could be passed).

Kenneth Goldsmith's Day (an 800 page retyping of one day's New York Times newspaper).

Kent Johnson's Day (an appropriation of Goldsmith's Day that Johnson created by placing a sticker bearing his name over the name of Goldsmith on copies of the book).

Towering above these pranks and gestures is Vanessa Place's Tragodía, a three volume set of court documents: Statement of Facts; Statement of the Case; and Argument. One 
entry in Statement of Facts begins by laying out the prosecution's case in a series of "facts":

On October 21, 2007, Ben was 13 years old, living with his family in Los Angeles. At 4:00 that Sunday morning, Ben was sitting alone on his front porch, reading his Bible. Appellant was walking down the street; he stopped at the gate and asked Ben about smoking. (RT 2:1831-1836, 2:1849-1850, 2:1871) Ben understood this to mean marijuana, and the two walked to an alley .... In the alley, they continued smoking. Ben felt his pants coming down; he tried unsuccessfully to pull them up. Appellant was behind Ben.... Ben felt appellant's penis penetrate his bottom, and remain there for five minutes. Appellant never asked Ben if he wanted to have sex. Ben had sex with appellant "out of curiosity." After Ben saw appellant ejaculate, Ben returned home.... Ben's mother Madison was on the porch; she asked Ben where he had been, and he eventually told her. She became upset, he embarrassed. Ben wrote a statement about what happened, saying he had been forced, which wasn't true. Ben wanted to have sex with appellant, but didn't what his mother to know that. Madison called the police.... (Place, 9)

As can be seen from this brief excerpt, presenting actual court documents relating to sexual crimes as if they were works of literature foregrounds the construction of narrative, the selection of detail (e.g. "Bible" mentioned above), the context they are placed into (on the porch with one's mother, or in a police station before an officer). It calls into question the politics (including class and gender politics) of constructed "truth" vs. fiction. Can there be a poetic truth in a courtroom? No hypothetical exercise, the narratives thus created in the name of the state bear close reading for their rhetorical constructions literally set some people free while sending others to Guantanamo. Conversely, Place's Tragodía questions the very morality of literary fiction by asking authors, how, at a time that includes continual war, political corruption, intellectual corruption, global warming, extinction on a mass scale-all problems that involve the creation of narrative-how at a time like this can anyone justify simply "making up stories"?

51 Which is to say that conceptual works are not all created equal. Given that the list of appropriated works presented as literature seems to be growing exponentially, it's bound to range from the profound to the banal as anyone can now become a (conceptual) author: just hold up a non-literary text and proclaim it art. So perhaps a more interesting question is to ask, Why do so many "authors" feel compelled to write such non-individualistic works-through appropriation, the use of machines, or crowdsourcing? And why did so many begin to do so at this moment in literary and extraliterary history?

\section{An Apology for Post-Literary Literature}

It's not as though Post-Literary Literature will come to be a dominate genre. As John Barth famously pointed out during the early days of postmodernism, there will always be authors working in a variety of registers; plurality is one of the distinguishing markers of our period, and even individuals employ multiple modes of writing/reading. Still, as earlier observers may have asked why Renaissance art emerged in Italy at the time that it did, so might we be rewarded by asking why is there so much post-literary literature emerging now? What does it say about our time and our place? And us? 
53 found objects as art at least since Marcel Duchamp exhibited a bicycle wheel or urinal as art; likewise, the literary canon is rife with collage, the quotation, the appropriation (see for example the poetry of Susan Howe, or the novels of Kathy Acker). Nor is this neo, post-literary literature Art Brut as Dubuffet meant it-art created outside the mainstream, often by unschooled artists (or writers). While some critics, readers, and many of the self-published authors described above simply do lack any literary sophistication, or even the craftsmanship associated with genre novels and poems, and while many critics themselves are increasingly turning away from aesthetics in the interest of sociological readings of popular forms, ${ }^{13}$ many sophisticated authors are intentionally working against the idea of an individual "author". And really, in the end, does it matter? Perhaps more telling, Is it inevitable? with which anyone can appropriate text, images, videos-really anything which can be digitized, which is to say anything-has surely altered ideas of the book, of originality, or ownership, and therefore, as this essay and many others have suggested, the concept of the lyric "I", in ways and to a degree that would have not been imagined even a few decades ago. (It would be hard to imagine teenagers caring about copyright laws, or even knowing such things existed, before Napster.) Part of the answer also seems to lie in Bök's observation that it's important for poets to take part in contemporary methods and discourses in order for poetry to stay relevant. This is especially true, he claims, given that information-processing technologies are rapidly becoming not only the means through which we read and write, but participate in virtually all aspects of culture (Voyce 2007). In other words, the sheer number of these kinds of works allows us to see a genre form before our eyes, along with its concomitant appreciation, criticism, and values. As always, the crude, the simple, the manipulative, the commercial, will continue to live beside more nuanced art, just as vaudeville lived beside theater, Hollywood blockbusters live beside art-house indie, and all kinds of books have always lived among each other (the death of the divides between high and low as well as literature and cultural studies or entertainment seems to be perpetually announced prematurely). From quill pens to the digital, the catalyst for change seems to be the tools that make new modes of thought, of writing, possible.

55 I began this essay with an image from 2001: A Space Odyssey, a fiction that proposed the first tool, the bone club, as an axis about which our earliest civilization turned. Others followed: Christianity, Capitalism.... Following the critique of Bruno Latour, it is easy to see how our digital tools, the self as pattern, our post-literary literature are all inseparable: three splashes in a pond that embraces all ripples in the surface they have created.

\section{BIBLIOGRAPHY}




\section{Works Cited}

BALL, James, “NSA data surveillance: how much is too much?", The Guardian, June 10, 2013, http://www.theguardian.com/world/2013/jun/10/nsa-metadata-surveillance-analysis? guni=Network\%20front:network-front\%20full-width-1\%20bento-box:Bento\%20box:Position2 (accessed 26 May 2014).

BENESON, Fred, ed. and compiler, Emoji Dick, http://www.emojidick.com/ (accessed 26 May 2014).

BÖK, Christian, “The Xenotext Experiment”, in R. Archambeau, D. Schneiderman, S. Tomasula, eds, The \&Now Awards, Lake Forest (IL), Lake Forest College Press, 2009.

BRUNS, Gerald, "On Ceasing to Be Human", Manuscript of the Roger Allan Moore Lecture at the Department of Social Medicine of the Harvard Medical School in April, 1998.

CHERNOFSKY, Phil, And Every Single One Was Someone, Jerusalem, Gefen Books, 2013, http:// www.gefenpublishing.com/product.asp?productid=1059

DAVIS, Wendy, Let Her Speak: Transcript of Texas State Senator Wendy Davis's June 25, 2013, Filibuster of the Texas State Senate, Denver, Counterpath Press, 2014.

FINLEY, Klint, “The Quantified Man: How an Obsolete Tech Guy Rebuilt Himself for the Future”, Wired, February 22, 2013, http://www.wired.com/2013/02/quantified-work/all/ (accessed 26 May 2014).

FOUCAULT, Michel, The Order of Things: An Archeology of the Human Sciences, New York, Vintage Books, 1973.

---, The Archaeology of Knowledge \& The Discourse on Language, New York, Pantheon, 1982.

FOISIL, Madeline, "The Literature of Intimacy", in A History of Private Life: Passions of the

Renaissance, Robert Chartier, ed, Arthur Coldhammer trans, Cambridge, Harvard University Press, 1989, 327-61.

GOLDSMITH, Kenneth, Day, The Figures, 2003.

GOPNIK, Adam, “Go Giants”, The New Yorker, April 21, 2014, 102-3.

GOULEMOT, Jean-Marie, “Literary Practices: Publicizing the Private", in A History of Private Life: Passions of the Renaissance, Robert Chartier, ed, Arthur Coldhammer trans., Cambridge, Harvard University Press, 1989, 363-95.

HAYLES, N. Katherine, How We Became Posthuman: Virtual Bodies in Cybernetics, Literature, and Informatics, Chicago, University of Chicago Press, 1999.

JASIEWICZ, Isia, “Self-publishing: Who Needs a Publisher Anymore?", Newsweek, August 9, 2010, vol. 156, Issue 6, 47.

JOHNSON, Bobby, "Privacy no longer a social norm, says Facebook founder", The Guardian, January 10, 2010, http://www.theguardian.com/technology/2010/jan/11/facebook-privacy (accessed May 26, 2014).

JOHNSON, Kent, Day, Kenmore (NY), BlazVOX Books, 2010.

JONADAB, “Black Perl Updated for Perl 5", PerlMonks, Online Posting, http:// www.perlmonks.org/?node_id=237465 (accessed 19 October 2010).

KAMINSKI, Margot, “The Critical Life of Information”, address to Conference on Big Data, Yale University, April 11, 2014. 
KENNEDY, Bill and DARREN Wershler-Henry, Apostrophe, Misfit Books, 2006, Apostrophe Engine Online, apostropheengine.ca (accessed May 26, 2014).

KHUN, Thomas, The Structure of Scientific Revolutions, Chicago, University of Chicago Press, 1996.

KOPALLE, Praveen, "Why Amazon's Anticipatory Shipping Is Pure Genius", Forbes, January 28, 2014, http://www.forbes.com/sites/onmarketing/2014/01/28/why-amazons-anticipatoryshipping-is-pure-genius/ (accessed May 26, 2014).

LATOUR, Bruno, We Have Never Been Modern, Catherine Porter trans., Cambridge, Harvard University Press, 1993.

LOHR, Steve, “How Privacy Vanishes Online," New York Times, March 16, 2010, http:// www.nytimes.com/2010/03/17/technology/17privacy.html?scp=10\&sq=data+mining\&st=nyt (accessed 21 October 2010).

LUKES, Steven, Individualism, ECPR Press, 2006.

MACPHERSON, C.B, The Political Theory of Possessive Individualism, Qtd. in Hayles,

Market Watch, http://www.marketwatch.com/investing/stock/amzn/financials (accessed May $26,2014)$.

MAU, Bruce, Massive Change, New York, Phaidon Press, 2004.

MORETTI, Franco, Graphs, Maps, Trees: Abstract Models for Literary History, London, Verso Press, 2005.

MONTFORT, Nick, “A 256-Character Program to Generate Poems”, Grand Text Auto, Online posting, http://grandtextauto.org/2008/02/15/a-256-character-program-to-generate-poems/ (accessed 19 October 2010).

--------- Narrative Science, Online posting, http://narrativescience.com/ (accessed May 26, 2014).

PACKER, George, "Cheap Words: Amazon is good for customers. But is it good for books?", The New Yorker, February 17, 2014, http://www.newyorker.com/reporting/ 2014/02/17/140217fa_fact_packer?currentPage=all (accessed May 26, 2014).

PARKER, Philip M., Personal email.

PLACE, Vanessa, Tragodía 1: Statement of Facts, Los Angleles, Insert Blanc Press, 2011.

QUENEAU, Raymond, “100,000,000,000,000 Poems”, in H. Matthews, Brotchie A. et al., eds, Oulipo Compendium, H. Matthews \& I. Monk trans., London, Atlas Press, 1998.

RAMIREZ, Edith, "Data Brokers: A Call for Transparency and Accountability," the Federal Trade Commission, May 2014, http://www.ftc.gov/system/files/documents/reports/data-brokers-calltransparency-accountability-report-federal-trade-commission-

may-2014/140527databrokerreport.pdf, cited in Ava Tomasula y Garcia, "Empty Sky: Cloud Technologies in the Global Landscape," draft ms.

SCHWEIZER, Tanja Sophie, "Multidedia Giants, Literary Publishers and New Technologies: Can Culture and Business Benefit from the Change of Rules in the Book World", International Journal of Arts Management, vol. 3, No. 3, Spring 2001, 51-67.

STREITFELD, David, and MELISSA Eddy, “As Publishers Fight Amazon, Books Vanish”, New York Times, May 23, 2014, http://bits.blogs.nytimes.com/2014/05/23/amazon-escalates-its-battleagainst-hachette/?_php=true\&_type=blogs\&_r=0 (accessed May 26, 2014). 
TABBI, Joseph, Reading Matters: Narrative in the New Media Ecology, Ithaca, Cornell UP, 1997.

THURSTON, Nick, Of The Subcontract, Or, On The Poetic Right, York, Information as Material, 2013, http://www.nickthurston.info/Of-the-Subcontract-Or-Principles-of-Poetic-Right

TUCKER, Patrick, “Has Big Data Made Anonymity Impossible?”, MIT Technology Review, May 7, 2013, http://www.technologyreview.com/news/514351/has-big-data-made-anonymityimpossible/?ref=rss (accessed 26 May 2014).

VOYCE, Stephen, “The Xenotext Experiment: An Interview with Christian Bök”, Postmodern Culture, 17.2, 2007, http://muse.jhu.edu.proxy.library.nd.edu/journals/postmodern_culture/toc/ pmc17.2.html (accessed 19 October 2010).

WATT, Ian, Studies in Defoe, Richardson and Fielding, Oakland, University of California Press, 1971.

Wattpad, “2013 Year on Wattpad”, http://2013.wattpad.com/ (accessed May 26, 2014).

WILKENS, Matthew, "Where Was the American Renaissance? Computation, Space, and Literary History in the Civil War Era", draft manuscript, 2013.

WOLF, Gary, “The Data-Driven Life”, The New York Times, April 28, 2010, http:// www.nytimes.com/2010/05/02/magazine/02self-measurement-t.html? scp=1\&sq=Gary\%20Wolf\%20the\%20data\%20driven\%20life\&st=cse/ (accessed May 26, 2014).

\section{NOTES}

1.

Screen Capture from Blue-Ray edition of 2001: A Space Odyssey. http://www.bluraydefinition.com/reviews/2001-a-space-odyssey-blu-ray-review.html (accessed 26 May 2014).

2.

Perhaps a high-water mark for this modernist, self-creating individual appears in Camus' The Stranger (L'Étranger). It begins with the famous opening lines: "Aujourd'hui, maman est morte. Ou peut-être hier, je ne sais pas."-a statement of Meursault's emotional, physical, and existential separation from his mother. In flattened, matter-of-fact language, the novel grows out of these opening lines to develop Meursault's isolation from all of those around him until physically isolated from society for killing a man, he sits in prison, awaiting his ultimate separation, that of his head from his body via the guillotine. He manages to reconcile himself to this fate by reminding himself that all people eventually come to a similar end, and indeed, anyone who can truly see human nature understands that each of us lives apart from others. He reconciles himself not to his fellow humans, but to this existential truth by imaging himself as far from the living as possible:

Pour que tout soit consommé, pour que je me sente moins seul, il me restait à souhaiter qu'il y ait beaucoup de spectateurs le jour de mon exécution et qu'ils m'accueillent avec des cris de haine.

"For everything to be consummated, for me to feel less alone, I had only to wish that there be a large crowd of spectators the day of my execution and that they greet me with cries of hate." [Matthew Ward trans.]

Camus once wrote that a novel was an image of a philosophy, and L'Étranger seems to be a stark example of a novel as an image of the philosophy of the human as an autonomous, self-creating, and therefore isolated, individual.

3.

Yale Law Professor Margot Kaminski notes that in 1973, the Code of Fair Information Practices came out of the U.S. as a legal framework for data policy. It focused on conceiving of Big Data harm. It said : that individuals have to be notified that databases exist; that individuals have to 
consent to their use ; that they can correct/amend info collected; that a database has to have integrity/safety; and that the individual must have some kind of redress for abuses of the database. The U.S. didn't adopt The Code of Fair Information Practices, though countries in the European Union did. The U.S. adopted a much weaker Privacy Act, which states that information gathered privately (by companies, not the U.S. government) is NOT governed by laws that are legally enforceable. In the U.S., the Big Data discussion is framed in terms of fairness and now security, instead of in language that makes it clear what is being collected by and about whom.

4.

Government entities, corporations and others maintain that mining the logs of these pings doesn't constitute spying since we voluntarily share this information by owning a phone (and agreeing to the privacy statements we were required to sign), and in any case, no one is listening in on the conversations ; indeed, there are no conversations to listen in on. But one example of how these logs are used goes like this :

Location records obtained from the phones of 4 people show that they have all visited the same address :

Person A made a short visit, and then a few days later returned for four hours.

Person B spent eight hours at the address, on a Saturday.

Person C spends 10 hours at the address each day.

Person D visits for a short period, weekly.

In this example, the address is an abortion clinic. A has had a consultation followed by an abortion. B works at the clinic, $\mathrm{C}$ is a protester, and D is a trans [gendered] person who needs to visit weekly for hormone injections. (Ball)

5.

See Chris Dancy's self-tracking grid (Klint). See also The Quantified Self Movement at http:// quantifiedself.com/guide/.

6.

And also nothing like novelists of old, we might also add, for we've come a long way since the days of Fenimore Cooper who published his first novel under the name "A Gentleman from New York" because to have one's private name in public print would have been considered vulgar.

7.

In this business sense, Amazon.com was sort of a proto-Facebook, trying to supply free "content" to get as big as possible as fast as possible. Having one foot in a pre-digital world, though, it still thought it needed actual physical products to attract users.

8.

Alexander Skipis, president of the German Publishers and Booksellers Association, put it bluntly : “...with such an online structure as pursued by Amazon, a book market is being destroyed that has been nurtured over decades and centuries" (Streitfeld and Eddy).

9.

Users of Amazon will be familiar with the most obvious of these, the Knn, or Nearest Neighbor, algorithm which searches for patterns in shoppers and matches them to the buying habits of other shoppers, i.e., 'Readers who bought THIS book also liked THAT book.'

10.

A few examples : after being rejected by 25 publishers, industrial engineer Boyd Morrison selfpublished his trilogy on Amazon where readers bought his novels at the rate of 4,000 books a month ; J. A. Konrath was also rejected by publishers till he began earning $\$ 100,000$ a year from sales of his self-published, mystery and horror novels. Amanda Hocking's self-published, paranormal romance novels have earned her \$ 2.5 million. When Hugh Howey's self-published sci-fi novel Wool began selling about 25,000 copies a month, he signed a contract with a mainstream publisher for the print rights, but continued serving as his own publisher for all digital copies. E.L. James, who did not start on Amazon but instead on a fan-fiction site run by a 
copy shop, recently became the Amazon Kindle's first 1 million seller (while also becoming the largest selling author of all time, even outselling J.K. Rowling).

11.

Maybe the most succinct description of the difference between literary and commercial publishing is summed up in the table Tanja Sophie Schweizer provides in her "Multimedia Giants, Literary Publishers and New Technologies : Can Culture and Business Benefit from the Change of Rules in the Book World."

12.

It is easy to see this ethos expressed in the plethora of visual art works in which isolated individuals are subsumed by groups. Using simple search tools, artist Jason Salavon located the formal portraits of hundreds of men whose family name is either Smith or Jones; he then used them to create his eponymous The Smith-Jones Checkerboard, where portraits of men with the last name Smith take the place of the black squares, and Jones the white (or is it the other way around ?). As in his Portrait Project, Salavon also digitally averages the pixels in every one of the Playboy centerfolds published during the 1980s (and other decades), to reveal "unexpected pattern as the relationship between the part and whole, the individual and the group" (http:// salavon.com/work/EveryPlayboyCenterfoldDecades/). Similarly, Benjamin Funke describes the chorus he assembled by synchronizing 100 videos of guys in their bedroom playing Metallica's "One" as "a painfully sincere musical community that exists only in a technologically mediated parallel reality" (http://www.benjaminfunke.com/p/teaching-philosophy.html) as do the 4,000 singers in Eric Whitacre's virtual choir, each recording his or her part separately, alone, then uploading them to Whitacre who assembles them as a choir (http://www.ted.com/talks/ eric_whitacre_a_virtual_choir_2_000_voices_strong - $t$-5412).

13.

As one review of Lawrence Buell's survey of American literature put it, "the difference between a beautifully written book and a badly written book [according to Buell] exists at about the same level as a politician's hair-it's something you might notice, but something that should not distract you..." (Gopnik, 103).

\section{AUTHOR \\ STEVE TOMASULA}

Notre Dame University, Chicago 